\title{
Unethical university operations: deception in disguise
}

\author{
Richard Hannis Ansah ${ }^{1}$ - Shahryar Sorooshian ${ }^{1}$
}

Published online: 19 September 2016

(C) Springer International Publishing AG 2016

\section{Letter to the Editor}

With the rise of the internet, the proliferation of higher education institutions, virtual and/or distance learning, and the multifaceted techno-social engineering innovations, fake academic institutions, and degree fraud have become a borderless issue that requires a global collaboration from government agencies and institutions to rid us of them. These misconducts and unethical operations have been escalating and expanding in number, operations, and sophistication in recent years and are mostly common in the developed economies.

Although there is wide and varied spectrum about the national guidelines for higher education accreditation, there are higher education institutions that are truly fake, agencies that design counterfeit of original degree and diploma certificates, and unaccredited institutions that provide educational activities and issue degrees that are not recognized by law or any educational system.

A greater number of fake institutions conceive themselves as members of national higher education systems, where there is no legal value for a degree or where the institutions receive their accreditations from private agencies recognized by the government and not directly by the government or by law. Typically, they imitate genuine institutions especially private colleges that specialize in adult education, specific certifications, and distance learning. Most bogus institutions use novel programming strategies with embedded website designs including supplanted "URL" and address bar appearance modification to look as though it originated from the original university. They maintain an illusion of providing a valid degree through their elaborate but highly misleading websites. They offer substandard and worthless degrees and sometimes award academic certificates within the shortest possible time without following any academic path or passing any kind of examination. Having these degrees

Richard Hannis Ansah

richanisah13@gmail.com

Shahryar Sorooshian sorooshian@gmail.com

1 Faculty of Industrial Management, Universiti Malaysia Pahang, Gambang, Malaysia 
may be worthwhile but may have no value in the long run. They are producing fake graduates which undermine the validity and reliability of higher education and could adversely affect industries and economies (Sorooshian 2016a).

It is worthwhile to mention the misconducts of accreditation mills or agencies. They are bogus agencies who award accreditation to institutions, without any recognition or standard educational requirements, to give them some sort of legal recognition. Their accreditation may be useless however it is used as a sort of trick to entice students.

Another instance is the modification of degree certificates and transcripts. Sellers of fake degrees are mostly acquainted with the latest designs software; they copy crests, stamps, logos, holograms, signatories, and wording, from certificates posted online, onto fake certificates and present them as genuine certificates for a ransom. This is similar to the admissions fraud (Ansah et al. 2016) and scholarly black market activities (Sorooshian 2016b). The danger is that they are producing bogus certificates that are eventually presented to unwitting employers.

Individuals need to be educated of this crime and encouraged to take preventive measures. Also, the sharing of graduation certificates online should be cautioned. Fraud agencies and the scientific communities must develop a robust university or degree verification toolkits to help individuals, employers, and higher education providers, as it is presently difficult to discern through the genuine and the fake.

\section{Compliance with ethical standards}

Conflict of interest None.

\section{References}

Ansah, R.H., D.O. Aikhuele, and L. Yao. 2016. Unethical admissions: Academic integrity in question. Science and Engineering Ethics. doi:10.1007/s11948-016-9815-9.

Sorooshian, S. 2016a. Fake graduates. Science and Engineering Ethics 1-2. doi: 10.1007/s11948-016-9784-z. Sorooshian, S. 2016b. Scholarly black market. Science and Engineering Ethics. doi:10.1007/s11948-016-9765-2. 